\section{Personlig om alderdom}

Hjort PF.

\section{Alderdom}

Helse, omsorg og kultur. 258 s, tab, ill. Oslo: Universitetsforlaget, 2010. Pris NOK 299 ISBN 978-82-15-01555-2

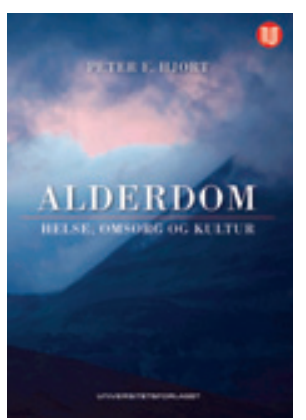

Alderdom bygger på forfatterens mangeårige undervisning for ulike grupper av helsepersonell samt kåserier for eldre mennesker. Det er ingen lett oppgave å tilfredsstille behovene til så mange og ulike

grupper i bokform, og det er vanskelig å vite hvem som er målgruppen, men vi blir jo alle eldre og må forholde oss til det.

Boken er delt i tre: Alderdommen (I), Helsetjenesten og eldreomsorgen (II) og Kultur, helse og alderdom (III). De 22 kapitlene er delt i mange underkapitler, der overskriftene både er formulerte påstander og retoriske spørsmål. Inndelingen er detaljert sett i forhold til de relativt korte avsnittene, men mange av overskriftene vekker min nysgjerrighet. Språket er personlig og relativt enkelt. Figurene illustrerer viktige poeng og gjenkjennes av dem som tidligere har hørt Hjort kåsere eller foredra. Utfordringer og dilemmaer for de eldre selv og for helsevesenet og samfunnet som skal forholde seg til dem, drøftes bredt med mange spennende innfallsvinkler.

Om målgruppen er uklar, tilhører forfatterstemmen den paternalistiske folkeopplyser. Som nestor i norsk medisin har han naturlig tyngde og interessante betraktninger og kan nok tillate seg å synse mer enn de fleste. Hjort har skrevet en ambisiøs og omfattende bok, og i det ligger både dens svakhet og dens styrke. Når alt skal nevnes, blir det både utilfredsstillende overfladisk og imponerende bredt.

Han omtaler barndom, ungdomstid, alderdom, helsepolitikk, medisinutdanning, sykehjemsmedisin, kunst og kultur, dyder og dødssynder samt medisinens villfarelser. På denne måten søker han å sette alderdommen i perspektiv og vise oss de sammenhengene han selv ser, noe som er både prisverdig og viktig. Men formen irriterer denne leseren; kan hende blir det for per- sonlig. Det er vanskelig å være mottakelig for råd eller søke erfaring både om det å være gammel, pårørende eller dyktig helsepersonell for gamle, og det å ta helsepolitiske beslutninger og gjøre riktige veivalg i medisinsk forskning. Forfatteren understreker riktignok tydelig at han gir uttrykk for egne meninger, provoserer litt med vilje og «legger det frem som påstander uten omstendelige begrunnelser». Men bokformatet, med mange kildehenvisninger, bør forplikte mer enn kåseriet når det gjelder å begrunne og utdype utsagn.

Best er han, synes jeg, når temaet er omsorg ved livets slutt. Med varme, klokskap, erfaring og finfølelse gir han oss både redskap og lyst til å utføre denne delen av legegjerningen bedre.

\section{Marte Mellingsæter}

Geriatrisk avdeling

Oslo universitetssykehus, Ullevål

\section{Overlevelsesbok for selvskadere}

Åkerman S.

For å overleve

En bok om selvskading. $212 \mathrm{~s}$, ill.

Oslo: Humanist forlag, 2010. Pris NOK 269

ISBN 978-82-92622-62-9

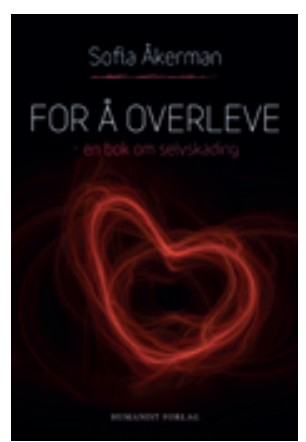

Selvskadende atferd er for alvor blitt et «nytt» fenomen innenfor ungdomskulturens randsoner. $\mathrm{Og}$ selvskading er på få år blitt langt mer synlig i mange medisinske praksiser. Slike fenomener opplever vi ofte som svært

utfordrende. De selvpåførte smertene utfordrer våre evner både til å forstå og handle på virksomme måter. Det trengs således stemmer som kan opplyse oss om selvskadingens vesen og fremme vår kompetanse til å møte slike fenomener.

Sofia Åkerman er i skandinavisk sammenheng blitt en slik røst. I 2005 fikk vi på norsk hennes selvbiografiske beretning Sebrapiken, om mange år med alvorlig selvskading og anorexia nervosa $(1,2)$. Den omfatter vanskelige ungdomsår, hvor mye tid ble tilbrakt både som frivillig og tvangsinnlagt i psykiatriske avdelinger. Teksten er viktig for en humanistisk medisin fordi den viser oss hvordan den subjektive virkeligheten til «den håpløse pasienten» kan fortone seg. Den er skrevet innenfra de erfaringene som vi som behandlere opplever utenfra. Og den gir oss mange triste eksempler på hvordan behandlere $\mathrm{og}$ pasient ikke evnet å møte hverandre på en konstruktiv måte. Men til sist lyktes det. Boken er skrevet ut fra posisjonen til den som har kommet seg gjennom selvdestruktiviteten, og har slik sett en lykkelig slutt.

Etter dette har Sofia Åkerman utdannet seg til sykepleier, og hun anvender nå mye av sin tid som forfatter og foredragsholder omkring slike tema. For å overleve. En bok om selvskading viser en slik bevegelse fra pasient til profesjonell. Hun bygger fortsatt på egne erfaringer, men denne boken bærer langt større preg av å være en faglig tekst som pedagogisk informerer om den selvpåførte skaden. Forfatteren skriver som en kollega til oss om definisjoner, forekomst, atferd, komorbiditet, suicidalitet og forståelsesmodeller. Og hun skriver ikke minst om selvskadens mange mulige funksjoner; hvor den overordnete er selvpåført smerte som en kroppspraksis for å regulere vanskelige følelser. Smerten er paradoksal fordi den kan lindre smerte. Når smerten flyttes fra det indre diffuse til det ytre konkrete, kan den være enklere å håndtere.

Dette er en bredt anlagt tekst hvor den faglige oversikten over feltet suppleres med en rekke kasuistiske eksempler, erfaringsnære beskrivelser, illustrasjoner og konkrete råd og tips. Og forfatteren retter seg både til fagfolk, til selvskaderne selv og til dem som står rundt. Boken kan absolutt anbefales, samtidig som den oppleves som langt mer konvensjonell enn den unike Sebrapiken. Og ettersom stabelen av selvhjelpsbøker på pulten min vokser, blir jeg slått av hvor like slike tekster blir (3). Det bør vel kanskje forstås som en god ting at de kloke rådene er ganske allmenne.

Finn Skårderud

Avdeling for helse- og sosialfag

Høgskolen i Lillehammer

\section{Litteratur}

1. Åkerman S. Sebrapiken. Oslo: Humanist Forlag. 2005 
2. Skårderud F. Skrift i huden - en selvskader forteller. Anmeldelse av boken: Åkerman S. Sebrapiken. Tidsskr Nor Lægeforen 2006; 126: 1106.

3. Skårderud F. Selvskading. Anmeldelse av boken Sutton J. Healing the hurt within. Tidsskr Nor Legeforen 2009; 129: 784-5.

\section{Til hjelp for hvem?}

Raknes S.

Psykologisk førstehjelp - Barn

64 s, ill. Oslo: Gyldendal Akademisk, 2010. Pris NOK 449

ISBN 978-82-05-40002-3

Raknes S.

Psykologisk førstehjelp - Ungdom

64 s, ill. Oslo: Gyldendal Akademisk, 2010

Pris NOK 449

ISBN 978-82-05-40003-0

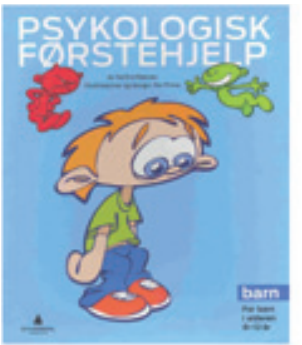

Dette materialet består av to skrin som er laget over samme lest. De har hvert sitt hefte hvor tekstens første del er myntet på foreldre og andre hjelpere, deretter er teksten rettet mot barn i alderen 8-12 år og ungdom 13-18 år. Skrinene inneholder også en rød plastfigur, som kan representere plagsomme eller skremmende tanker, og en grønn plastfigur, som kan stå for hjelpsomme tanker, f.eks. «jeg kommer til å greie det». Videre er det en blokk «hjelpehender» for utfylling. Dette er et ark med tegning av en hånd, med overskrifter som viser hvilke kategorier det er lurt å skille mellom: Hva skjer? (tommelfinger), Følelser (pekefinger), Rødtanker (langfinger), Grønntanker (ringfinger), Hva kan jeg gjøre? (lillefinger) og Hvem kan hjelpe meg? (håndflate). Hånden skal være et hjelpemiddel når tanker og følelser blir vanskelige og uoversiktlige. Forfatteren oppfordrer den voksne som skal bistå barn, til å øve selv før hun/han hjelper barnet. I heftet gir hun råd om hvordan man best kan gjøre dette.

Forfatteren er psykologspesialist. Tekstene hennes er kanskje litt «snusfornuftige», men logisk bygd opp og lette å lese. Tegningene til industridesigner Per Finne følger teksten. De er morsomme og appellerer til barn, men for eldre tenåringer kan de nok oppfattes som litt barnslige.

Dette materialet bygger på prinsipper for kognitiv terapi som vi vet kan være nyttige i behandlingen av psykiske lidelser, bl.a. angst og depresjon. Men utover å navngi norske fagfolk som har fungert som referansegruppe, inneholder heftene ingen litteraturreferanser eller informasjon om annet tilgjengelig materiale, beregnet på voksne som ønsker å hjelpe barn til å mestre følelsesmessige vansker på en hensiktsmessig måte.

Jeg er i tvil om foreldre til barn som ikke har spesielle problemer, vil bruke dette materialet. Likevel mener jeg at stoffet kan gi noen hver ideer om hvordan de kan hjelpe barn, ikke bare ved å trøste, men ved å bidra til at barna kan se situasjonen fra nye sider, finne løsninger og bli bevisst hvor de kan hente støtte og hjelp. Samlet sett oppfatter jeg derfor heftene som potensielt nyttige. Barn som har positive forventninger og tendens til å tolke det som skjer på en positiv måte, vil nok generelt være mer tilfreds og ha mindre risiko for å få psykiske symptomer, men så spørs det i hvilken grad slike egenskaper er noe man kan trene opp?

Det er vel dette som er målet med heftene, som nok egner seg best brukt i førstelinje psykologisk tjeneste eller i grupper, f.eks. på helsestasjonen der metoden kan presenteres av noen som kan den, stoffet kan diskuteres, og foreldre, barn og ungdom kan ta materialet med hjem og fortsette å bruke det hjemme. Men det kan også være greit at leger, som møter barn og unge i sin kliniske virksomhet, kjenner til dette materialet og kan henvise til det der det er indisert.

\section{Inger Helene Vandvik}

Slependen

\section{Fin oversikt over embryonale stamceller}

Simón C, Pellicer A, red.

Stem cells in human reproduction

Basic science and therapeutic potential. 2.utg.

262 s, tab, ill. London: Informa Healthcare,

2009. Pris GBP 135

ISBN 978-0-4154-7171-8

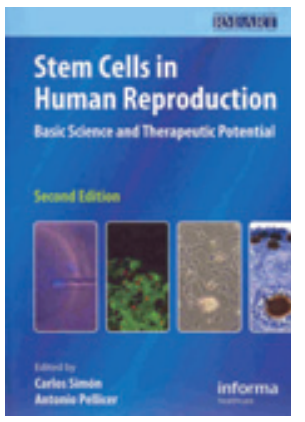

Målgruppen er dem som arbeider med forskjellige aspekter av reproduksjonsmedisin og har interesse av å holde seg orientert om den nyeste utviklingen innen forskning, utvikling og anvendelse av embryonale stamceller. Boken består av fem seksjoner (I-V), som er bygd opp rundt et spesielt tema og består av flere velskrevne, veldokumenterte og fint illustrerte artikler, totalt 21 .
De fire første seksjonene er en oppdatering av den første utgaven (2007) og inneholder artikler som diskuterer stamcellers potensial i forhold til utviklingen av gameter, trofoblast- og endometrial celler som muligens kan anvendes i nye måter å behandle infertilitet på i fremtiden. I seksjon $\mathrm{V}$ tar forfatterne for seg forskningsutviklingen basert på humane embryonale stamceller. Her rapporterer man fra studier om hvordan humane embryonale stamceller (human embryonic stem cells, hESC) kan anvendes til å studere embryoimplantasjon ved å benytte seg av in vitro-modeller, og hvordan man kan utvikle embryonale stamceller uten å måtte bruke overtallige humane embryo, som kan være etisk betenkelig for mange. Det kan være mulig å anvende andre prosedyrer slik som omprogrammering av somatiske celler, oocyttaktivering, embryobiopsier, som ved preimplantatorisk genetisk diagnostikk (PGD), eller ved kjerneoverføring (terapeutisk kloning).

Utfordringen er å dyrke embryonale stamceller og utvikle celler/vev for mulig bruk i behandling basert på regenerativ medisin. Sykdommer som er kandidater for slik behandling i fremtiden, inkluderer hjertesykdommer, diabetes og nervesystemssykdommer slik som Parkinsons sykdom. Begrensende faktorer ligger på utviklingen av embryonale stamcellelinjer og deres potensial til å utvikle seg til nye, differensierte celler som kan erstatte eller reparere skadet eller sykt vev.

Dette verket er en fin oversikt og en verdifull referansekilde for dem som er interessert i å få innsikt i embryonale stamcellelinjer og deres mulige fremtidige anvendelse $\mathrm{i}$ både reproduktiv og regenerativ medisin. Jeg vil fremheve kapittel 6 av Gosden og medarbeidere, som tar opp to kontroversielle rapporter som hevder at oocytter fornyes kontinuerlig i løpet av det reproduktive livet $(1,2)$. Dette utfordrer konsensusoppfatningen om at den totale populasjonen av oocytter i ovariene til pattedyr dannes bare én gang. Påstandene fra forfatterne av rapportene blir avkreftet, men Gosden konkluderer med at man ikke kan utelukke at det eksisterer pluripotente celler i ovariene som under spesielle omstendigheter kan induseres til å generere nye kimceller.

\section{Ritsa Storeng}

Kvinne- og barneklinikken

Oslo universitetssykehus, Rikshospitalet

\section{Litteratur}

1. Johnson J, Canning J, Kaneko T et al. Germline stem cells and follicular renewal in the postnatal mammalian ovary. Nature 2004; 430: 1062.

2. Johnson J, Bagley J, Skaznik-Wikiel M et al. Oocyte generation in adult mammalian ovaries by putative germ cells in bone marrow and peripheral blood. Cell 2005; 122: 303-15 